\title{
A taxonomic revision of small neotropical saurian malarias allied to Plasmodium minasense
}

\author{
by S. R. TELFORD Jr. * \\ The Florida State Museum, University of Florida, Gainesville, Florida, \\ U.S.A. 32611.
}

\section{Résumé.}

\begin{abstract}
Revue taxonomique des Plasmodium sauriens de petite taille appartenant au groupe des Plasmodium minasense.
\end{abstract}

Les espèces de Plasmodium sauriens qui produisent des schizontes plus petites que les noyaux normaux des érythrocytes, avec 4 à 8 mérozoïtes, et des gamétocytes plus petits ou de même taille que les noyaux des érythrocytes et qui infectent les lézards des familles Scincidae, Iguanidae et Teiidae dans les régions néotropiques, sont considérés comme étant des Plasmodium minasense Carini et Rudolph, 1912. Des désignations de sous-espèces sont données pour que les populations parasitant différentes espèces d'hôtes puissent être distinguées : $P$. minasense minasense est reconnu parasite de l'hôte type Mabuya mabouya; $P$. minasense carinii Léger et Mouzels, 1917, celui d'Iguana iguana de la région côtière de l'Amérique du Sud; P. minasense anolisi subsp. nov. d'Anolis limifrons du Panama; P. minasense capitoi subsp. nov. de Anolis capito du Panama; P. minasense plicae subsp. nov. de Plica umbra de Guyane; $P$. minasense tegui subsp. nov. de Tupinambis teguixin du Venezuela ; et $P$. minasense diminutivum Telford, 1973, nouvelle utilisation, celui de Ameiva ameiva du Panama. Plasmodium rhadinurum Thompson et Huft, 1944 est maintenant reconnu comme une espèce distincte sur la base des traits suivants : il possède des schizontes de forme différente, des stades asexués avec projections filamenteuses dans la plupart des zones géographiques et des gamétocytes plus grands, enfin une apparente sympatrie avec $P$. minasense carinii dans certaines régions.

* Current address : Rodent Control Demonstration Unit, c/o The WHO Program Coordinator, P.O. Box 14, Rangoon, Burma.

Accepté le 23. janvier 1979. 


\section{Summary.}

Saurian malaria species which produce schizonts smaller than normal erythrocyte nuclei, with 4-8 merozoites and gametocytes equal to or smaller than erythrocyte nuclei in size, parasitizing hosts of the lizard families Scincidae, Iguanidae and Teiidae in the Neotropics are considered to be Plasmodium minasense Carini and Rudolph, 1912. Subspecific designations are given to distinctive populations parasitizing different host species: $P$. minasense minasense is recognized from the type host, Mabuya mabouya of Brasil ; $P$. minasense carinii Leger and Mouzels, 1917 from Iguana iguana of coastal South America ; P. minasense anolisi subsp. nov. from Anolis limifrons of Panama; P. minasense capitoi subsp. nov. from Anolis capito of Panama; P. minasense plicae subsp. nov. from Plica umbra of Guyana; $P$. minasense tegui subsp. nov. from Tupinambis teguixin of Venezuela; and P. minasense diminutivum Telford, 1973, new combination, from Ameiva ameiva of Panama. Plasmodium rhadinurum Thompson and Huff, 1944 is recognized as a distinct species at present on the basis of possessing schizonts of different shape, asexual stages with filamentous projections in most portions of its range, and larger gametocytes, as well as apparent sympatry with $P$. minasense carinii in some areas.

There have been four distinct treatments of small malarial parasites found in various saurians from Panama south into Brasil. Plasmodium minasense was described from the skink Mabuya agilis (= M. mabouya) by Carini and Rudolph (1912) with a minimum of detail often encountered in earlier descriptions. Differences in host family and gametocyte size notwithstanding, Wenyon (1915) considered a small Plasmodium species from Iguana sapidissima $(=I$. iguana) of Trinidad to be $P$. minasense, a decision consistent with his known reluctance to recognize new species. It is possible that Wenyon was dealing with two small Plasmodium species in Trinidad iguanas. His schizonts (1915: fig. 6-12) and gametocytes (fig. 14, 15) are similar to those I consider to be P. minasense carinii among my material. Young asexual stages of this species are not usually elongated as shown in Wenyon's figures 2-5. These could have been $P$. rhadinurum which does not always show as prominently the filamentous cytoplasmic projections characteristic of the type population (Colima, Mexico) throughout its range. Wenyon's figures 13 and 16, in my opinion, are those of a haemococcidian, probably Lainsonia iguanae. Leger and Mouzels (1917) described but did not depict what may have been some of the same parasites Wenyon found as $P$. carinii from Iguana nudicollis of Guyana. Ayala (1978) considers the host to have been I. iguana, as I. nudicollis is an Antillean species. Garnham (1966) recognized the obvious differences between the skink and iguana parasites by use of the trinomial for the latter. Telford $(1973 b)$ identified a small Plasmodium from Plica umbra and P. plica of Guyana as P. minasense, without comment. Later (1974), I characterized populations of the small Plasmodium species in Panamanian anoles as $P$. minasense sensu lato, but troubled by obvious differences between samples from three host species and a too simple acceptance of Wenyon's approach to this group of very similar parasites, I indicated my doubts of their conspecificity. I have recently 
(1979) considered the samples from Analis frenatus to represent crisis forms of Plasmodium marginatum, a species described from that host.

Ayala and Spain (1976) synonymized $P$. minasense with $P$. tropiduri, recognized $P$. carinii for the small iguana malarias, and considered $P$. rhadinurum Thompson and Huff, 1944 to be a synonym of $P$. carinii without presenting justification. I have indicated disagreement with their opinions (Telford, 1977) and suggested that these small Plasmodium parasites represent strains of $P$. minasense s.l. evolving in different host families. I think the approach taken by Garnham (1966) in use of the trinomial is justified as the most realistic classification possible until more precise relationships can be defined by modern biochemical techniques. Each population of these small, similar plasmodiids parasitizing hosts of different family or species is therefore recognized as a host race or subspecies where distinct, supporting the concept of an ancestral stock of small parasites evolving along with saurian families as they have diversified since the Mesozoic.

Taxonomic summaries prepared from literature descriptions and from my data are presented below with subspecies designations for those populations which appear to be sufficiently distinct for recognition.

\section{Materials and methods}

The taxonomic characters used here are those described in earlier studies (Telford, 1974, 1979). The material from Panamanian lizards was collected as described earlier (Telford, $1973 a, 1974$ ) as was that from Guyana (Telford, $1973 b$ ) and Venezuela (1978). A series of young Iguana iguana showing new Plasmodium infections was given by a commercial animal dealer to the Florida State Museum in April 1973. Their origin, as far as I have been able to determine, was probably in the vicinity of Barranquilla, Colombia.

Gametocytes were considered to be mature when sexes could be distinguished by staining reaction accompanied by dispersal of pigment granules. In some populations, microgametocytes characteristically show aggregation of pigment granules in one or two foci, but it is usually possible to determine if these are comprised of discrete granules in contrast to the solid mass characteristic of immature gametocytes. Quantitative data are presented in Tables I and II.

Paratype material from all populations except $P$. minasense minasense has been deposited with Professor A. Chabaud, Museum de l'Histoire Naturelle, Paris. Syntype slides of new subspecies are in the Telford collection.

\section{Results}

Plasmodium minasense Carini and Rudolph, 1912.

DÉfinition. - A small saurian Plasmodium species characterized by having schizonts equal to or smaller than nuclei of uninfected erythrocytes, and gametocytes 
Table I. - Variation in schizont samples from Plasmodium minasense populations.

\begin{tabular}{|c|c|c|c|c|c|c|c|}
\hline \multirow[b]{2}{*}{ Host species } & \multirow[b]{2}{*}{ Locality } & \multirow[b]{2}{*}{$\begin{array}{l}\text { Infection } \\
\text { stage }\end{array}$} & \multirow[b]{2}{*}{$\mathrm{N}$} & \multicolumn{4}{|c|}{ Schizont characters } \\
\hline & & & & $\begin{array}{l}\text { length } \\
(\mu \mathrm{m})\end{array}$ & $\begin{array}{l}\text { width } \\
(\mu \mathrm{m})\end{array}$ & $\begin{array}{c}\text { LW } \\
\left(\mu \mathrm{m}^{2}\right)\end{array}$ & $\begin{array}{c}\text { no. } \\
\text { nuclei }\end{array}$ \\
\hline & & & & \multicolumn{4}{|c|}{ Mean values } \\
\hline Iguana iguana ......... & Colombia? & active & 25 & $4.1 \pm .1$ & $3.0 \pm .1$ & $11.8 \pm .6$ & $4.2 \pm .2$ \\
\hline Anolis limifrons ........ & Panama & « & 25 & $4.5 \pm .1$ & $3.5 \pm .1$ & $15.8 \pm .6$ & $6.1 \pm .2$ \\
\hline " & " & acute & 50 & $4.5 \pm .3$ & $3.5 \pm .3$ & $15.6 \pm .5$ & $5.8 \pm .3$ \\
\hline Anolis capito ........... & Panama & active & 25 & $4.7 \pm .1$ & $3.6 \pm .1$ & $17.2 \pm .8$ & $4.6 \pm .2$ \\
\hline " & " & " & 25 & $5.1 \pm .2$ & $3.6 \pm .1$ & $18.8 \pm .9$ & $4.5 \pm .2$ \\
\hline Plica umbra ............ & Guyana & acute & 25 & $4.0 \pm .2$ & $2.8 \pm .1$ & $11.1 \pm .7$ & $5.0 \pm .3$ \\
\hline Tupinambis teguixin .. & Venezuela & active & 25 & $3.7 \pm .1$ & $3.2 \pm .1$ & $12.0 \pm .6$ & $4.2 \pm .1$ \\
\hline " & " & a & 25 & $4.8 \pm .1$ & $3.7 \pm .1$ & $17.7 \pm .8$ & $4.3 \pm .1$ \\
\hline Ameiva ameiva ....... & Panama & active & 25 & $3.9 \pm .1$ & $3.2 \pm .1$ & $12.2 \pm .5$ & $4.2 \pm .1$ \\
\hline \multirow[t]{2}{*}{ “ } & " & acute & 25 & $3.8 \pm .1$ & $3.1 \pm .1$ & $12.0 \pm .4$ & $4.3 \pm .1$ \\
\hline & & & \multicolumn{5}{|c|}{ Range of variation } \\
\hline Iguana iguana .......... & Colombia? & active & 25 & $3-5$ & $2-4$ & $6-20$ & $4-8$ \\
\hline Anolis limifrons ....... & Panama & « & 25 & $4 \cdot 6$ & $3-4$ & $12-24$ & $4-8$ \\
\hline " & " & acute & 50 & $4-8$ & $2-4$ & $8-24$ & $4-8$ \\
\hline Anolis capito ............ & Panama & active & 25 & $3-6$ & $3-5$ & $9-25$ & $4-8$ \\
\hline " & « & " & 25 & $4-7$ & $3-4$ & $12-28$ & $4-8$ \\
\hline Plica umbra ............ & Guyana & acute & 25 & $3-6$ & $2-4$ & $6-18$ & $4-8$ \\
\hline Tupinambis teguixin .. & Venezuela & active & 25 & $3-5$ & $3-4$ & $9-20$ & $4-6$ \\
\hline " & " & " & 25 & $4-6$ & $3-5$ & $12-25$ & $4-6$ \\
\hline Ameiva ameiva ........ & Panama & active, & 25 & $3-5$ & $3-4$ & $9-20$ & $4-6$ \\
\hline " & $\alpha$ & acute & 25 & $3-4$ & $3-4$ & $9-16$ & $4-6$ \\
\hline
\end{tabular}

which may slightly exceed these nuclei in size but which are usually smaller. Segmenters produce 4-8 merozoites with the mean number usually less than 6 . All stages past young schizonts are pigmented. Gametocytes parasitize erythrocytes and appear to be common only immediately following acute phase of infection, and are often apparently absent, with infection recognized by presence of asexual stages alone. Neither host cell nor its nucleus is distorted by presence of the parasite.

RANGE. - Southern Middle America to southern Brasil, and possibly present in Southeast Asia.

Hosts. - Parasites similar to the definition above are known from the saurian families Scincidae, Iguanidae and Teiidae of the Western Hemisphere, and occur in Agamidae of Malaysia as well (Laird, 1960). Strains in each host family and in 
some species within a family are distinctive and can be differentiated taxonomically as subspecies.

Table II. - Variation in gametocyte samples from Plasmodium minasense populations.

\begin{tabular}{|c|c|c|c|c|c|c|c|}
\hline \multirow[b]{2}{*}{ Host species* } & \multirow[b]{2}{*}{$\begin{array}{l}\text { Infection } \\
\text { Stage }\end{array}$} & \multirow[b]{2}{*}{$\mathrm{N}$} & \multicolumn{5}{|c|}{ Gametocyte characters } \\
\hline & & & $\begin{array}{l}\text { length } \\
(\mu \mathrm{m})\end{array}$ & $\begin{array}{l}\text { width } \\
(\mu \mathrm{m})\end{array}$ & $\begin{array}{l}\mathrm{LW} \\
\left(\mu \mathrm{m}^{2}\right)\end{array}$ & $\begin{array}{l}\mathrm{L} / \mathrm{W} \\
\text { ratio }\end{array}$ & $\begin{array}{l}\mathrm{LW} / \text { host cell } \\
\text { nucleus LW }\end{array}$ \\
\hline & & \multicolumn{6}{|c|}{ Mean values } \\
\hline Iguana iguana .... & active & 3 & 4.3 & 3.7 & 16.0 & 1.19 & 0.67 \\
\hline Anolis limifrons ....... & active & 25 & $5.7 \pm .2$ & $4.9 \pm .2$ & $28.1 \pm .2$ & $1.19 \pm .04$ & $0.66 \pm .01$ \\
\hline “ & chronic & 25 & $5.6 \pm .2$ & $4.8 \pm .2$ & $27.1 \pm .2$ & $1.19 \pm .02$ & $0.72 \pm .01$ \\
\hline “ & “ & 25 & $4.7 \pm .1$ & $4.2 \pm .1$ & $19.4 \pm .8$ & $1.11 \pm .02$ & $0.52 \pm .03$ \\
\hline Anolis capito .......... & active & 25 & $7.2 \pm .3$ & $4.8 \pm .2$ & $34.8 \pm .1 .4$ & $1.54 \pm .06$ & $0.84 \pm .03$ \\
\hline " & " & 25 & $7.0 \pm .3$ & $5.0 \pm .2$ & $35.0 \pm .1 .2$ & $1.45 \pm .07$ & $1.01 \pm .04$ \\
\hline Plica umbra ........... & acute & 25 & $5.3 \pm .1$ & $4.2 \pm .1$ & $22.2 \pm .8$ & $1.28 \pm .03$ & $0.61 \pm .02$ \\
\hline Tupinambis teguixin .. & active & 25 & $4.3 \pm .1$ & $3.8 \pm .1$ & $16.3 \pm .6$ & $1.16 \pm .03$ & $0.63 \pm .02$ \\
\hline \multirow[t]{2}{*}{ Ameiva ameiva ....... } & active & 22 & $5.9 \pm .2$ & $4.4 \pm .2$ & $26.1 \pm .1 .6$ & $1.40 \pm .08$ & $0.90 \pm .04$ \\
\hline & & & \multicolumn{5}{|c|}{ Range of variation } \\
\hline Iguana iguana ......... & active & 3 & $4-5$ & $3-4$ & $12-20$ & $1.0-1.3$ & $0.5-0.8$ \\
\hline Anolis limifrons ....... & active & 25 & $5-7$ & $3-6$ & $15-36$ & $1.0-1.7$ & $0.3-1.0$ \\
\hline " & chronic & 25 & $5-7$ & $4-6$ & $20-42$ & $1.0-1.5$ & $0.4-1.1$ \\
\hline " & « & 25 & $4-6$ & $4-5$ & $16-30$ & $1.0-1.3$ & $0.4-0.9$ \\
\hline Anolis capito .......... & active & 25 & $5-9$ & $3-6$ & $21-48$ & $1.0-2.3$ & $0.5-1.2$ \\
\hline " & “ & 25 & $6-9$ & $4-6$ & $24-45$ & $1.0-2.3$ & $0.6-1.5$ \\
\hline Plica umbra ........... & acute & 25 & $4-6$ & $4-5$ & $16-30$ & $1.0-1.5$ & $0.5-0.8$ \\
\hline Tupinambis teguixin .. & active & 25 & $4-5$ & $3-4$ & $12-20$ & $1.0-1.3$ & $0.4-0.8$ \\
\hline Ameiva ameiva ....... & active & 22 & $5-9$ & $3-6$ & $18-42$ & $1.0-2.0$ & $0.6-1.5$ \\
\hline
\end{tabular}

$\left(^{*}\right)$ Localities same as in Table $I$.

\section{Diagnoses of subspecies}

Plasmodium minasense minasense Carini and Rudolph, 1912.

Diagnosis. - A parasite of scincid lizards. Schizonts fan-shaped, with 4 merozoites, approximately $5 \times 4 \mu \mathrm{m}$, similar in size (LW) to nuclei of uninfected erythrocytes. Gametocytes approximately 5-6 $\times$ 4-5 $\mu \mathrm{m}$, with $\mathrm{LW}$ values $23-30$ and $\mathrm{L} / \mathrm{W}$ ratio 1.2-1.4. Ratio of gametocyte LW to host cell nucleus LW 1.1-1.3. Source of data: original description (fig. 1, 50-52). 

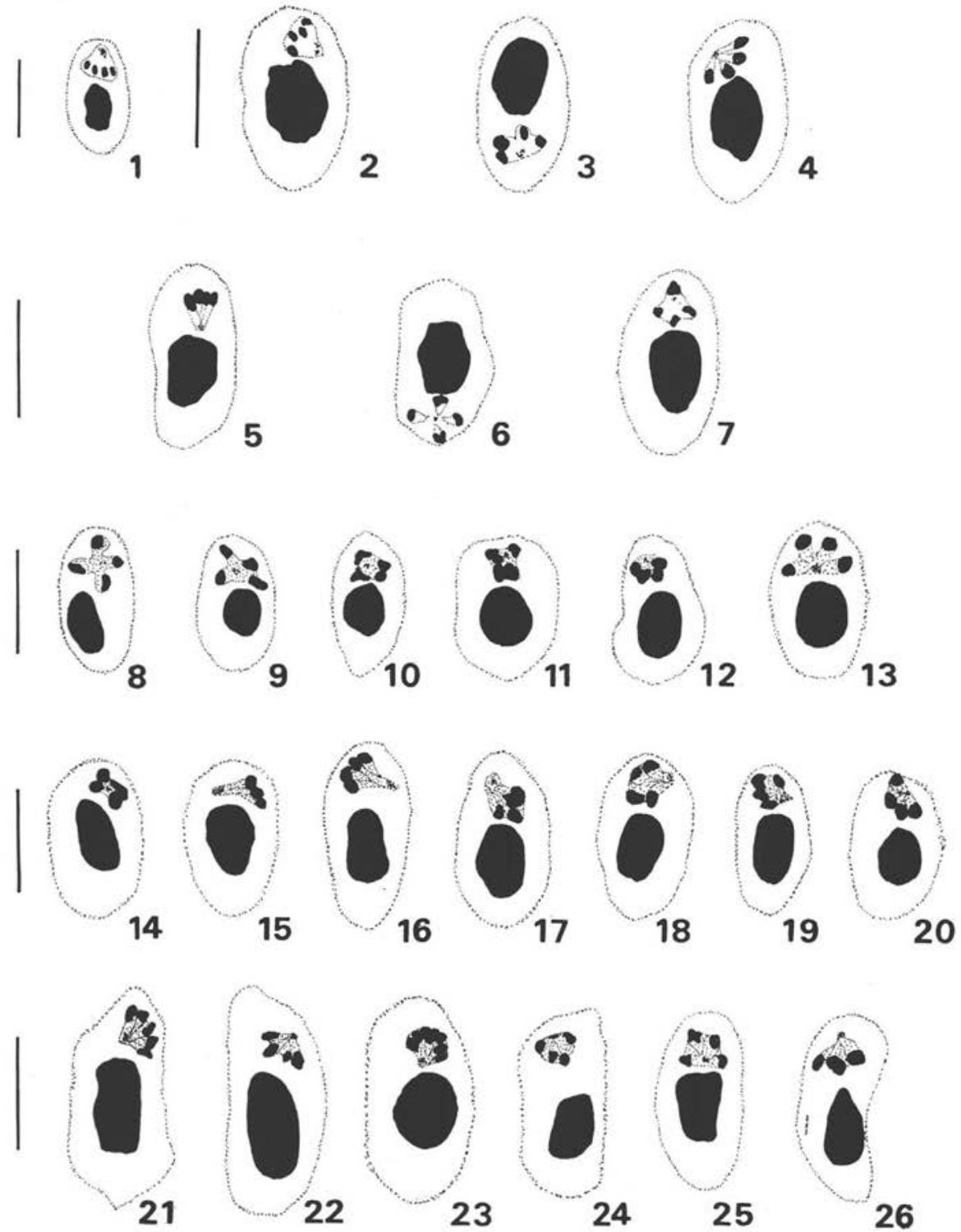

Fig. 1. Schizont of Plasmodium minasense minasense from original description by Carini and Rudolph 1912

Fig. 2-7. Schizonts supposedly of $P$. minasense carinii from Wenyon, 1915

Fig. 8-13. Schizonts of $P$. rhadinurum, Colima, Mexico

Fig. 14-20. Schizonts of $P$. rhadinurum, Estado Portuguesa, Venezuela

Fig. 21-26. Schizonts of $P$. minasense carinii supposedly from vicinity of Barranquilla, Colombia

Vertical bars to left of figures represent $10 \mu \mathrm{m}$ 
Host SPecies. - Mabuya agilis (Scincidae), type host (= M. mabouya).

GeOgRaphic RANGe. - Known only from the type locality, River Paranahyba and its tributary Bagagem, Minas Gerais, Brasil.

LOCATION OF TYPES. - Unknown, presumed lost.

Plasmodium minasense carinii Leger and Mouzels, 1917.

Diagnosis. - A parasite of iguanid lizards. Schizonts broadly fan-shaped, occasionally cruciform at segmentation, 3-5 $\times 2-4 \mu \mathrm{m}$, usually less than half the size (LW) of nuclei in uninfected erythrocytes. Segmenters contain 4-8 merozoites. Immature forms lack long, filamentous cytoplasmic projections and are usually rounded, occasionally with an inconspicuous vacuole, but may show one or two short, digitiform processes. Gametocytes, rarely seen in circulating blood and inadequately described, measure approximately 5-7 $\times 3-4 \mu \mathrm{m}$, with $\mathrm{LW}$ values $26-28$ and L/W ratios $1.6-1.8$. Ratio of gametocyte LW to that of host cell nuclei 0.9-1.1. Source of data: Leger and Mouzels, 1917; Wenyon, 1915 (fig. 2-7, 53, 54); material in Telford collection (fig. 21-26, 55-57).

GeOGRAPHIC RANGE. - Type locality presumed to be vicinity of Cayenne, French Guiana. Probable range is along the coast of South America from Bahia, Brasil to Colombia and on Trinidad. Only precise locality known is Salvador, Bahia for material collected by M. Miles and sent to Professor Garnham. Slides in Telford collection are from a series of $I$. iguana collected presumably in the vicinity of Barranquilla, Colombia by a commercial collector.

Host SPecies. - Iguana iguana (Iguanidae). Type host I. nudicollis probably was I. iguana (Ayala, 1978).

Plasmodium minasense anolisi subsp. nov.

Diagnosis. - A parasite of anoline lizards. Schizonts are one-half to two-thirds size of normal erythrocyte nuclei, $4-8 \times 2-4 \mu \mathrm{m}$, with $4-8$ merozoites arranged as a fan or rosette. Schizonts in proerythrocytes are significantly larger than those parasitizing erythrocytes and contain two more merozoites, on average. Gametocytes are 4-7 $\times 3-6 \mu \mathrm{m}$, with $\mathrm{LW}$ values $15-42$ and $\mathrm{L} / \mathrm{W}$ ratios 1.0-1.7. Ratio of gametocyte LW to host cell nucleus LW 0.3-1.1. Pigment usually focussed in one or two loci in mature gametocytes. Young asexual stages irregularly shaped, often with distinct vacuole. Source of material: Telford collection (fig. 27-30, 62-65).

Host SPECIES. - Anolis limifrons (Iguanidae), type host.

Geographic RAnge. - Type locality is Frijoles River, $4.8 \mathrm{~km}$ N Gamboa, Canal Zone, Panama. Known from Canal Zone and San Blas Territory, Panama. 

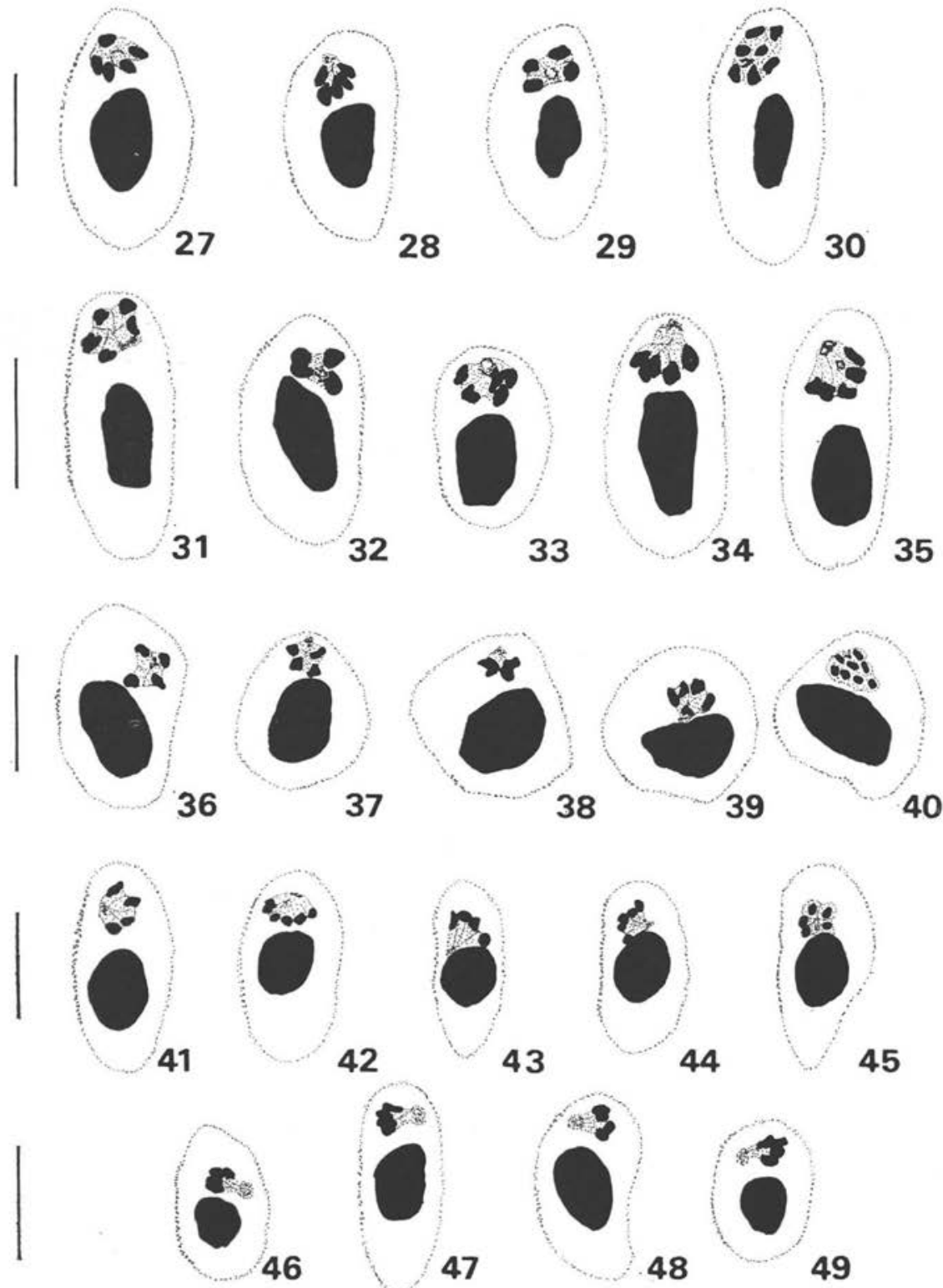

Fig. 27-30. Schizonts of $P$. minasense anolisi, Panama

Fig. 31-35. Schizonts of $P$. minasense capitoi, Panama

Fig. 36-40. Schizonts of $P$. minasense plicae, Guyana

Fig. 41-45. Schizonts of $P$. minasense tegui, Venezuela

Fig. 46-49. Schizonts of $P$. minasense diminutivum, Panama

Vertical bars to left of figures represent $10 \mu \mathrm{m}$ 
Plasmodium minasense capitoi subsp. nov.

Diagnosis. - A parasite of the terrestrial forest anole, Anolis capito. Schizonts one-fourth to three-fourths size of uninfected erythrocyte nuclei, 3-7 $\times 3-5 \mu \mathrm{m}$, with 4-8 nuclei, variably shaped but frequently cruciform or as a fan. Gametocytes 5-9 $\times 3-6 \mu \mathrm{m}$, with LW values $21-48$ and $\mathrm{L} / \mathrm{W}$ ratios $1.0-2.3$. Ratio of gametocyte LW to that of host cell nuclei $0.5-1.5$. Schizonts and gametocytes heavily pigmented, with pigment dispersed in large black granules in gametocytes. Vacuoles prominent in both young asexual stages and gametocytes. Source of material: Telford collection (fig. 31-35, 66-69).

Host species. - Anolis capito (Iguanidae), type host.

GeOgraphic RANGe. - Known only from the type locality, Frijoles River, $4.8 \mathrm{~km}$ N Gamboa, Canal Zone, Panama.

Plasmodium minasense plicae subsp. nov.

Diagnosis. - A parasite of Plica spp. (Iguanidae). Schizonts less than half the size of normal erythrocyte nuclei, $3-6 \times 2-4 \mu \mathrm{m}$, with $4-8$ merozoites arranged as a short fan, rarely as a morula. Asexual parasites become fan-shaped early, often before nuclear division begin, and tend to lie along the periphery of erythrocytes. Gametocytes usually nucleophilic and commonly vacuolated, 4-6 $\times 4-5 \mu \mathrm{m}$, with LW values $16-30 \mu \mathrm{m}^{2}$ and $\mathrm{L} / \mathrm{W}$ ratios 1.0-1.5. Ratio of gametocyte LW to that cell nucleus $0.5-0.8$. Pigment dark greenish-gold to black in gametocytes when dispersed, and prominent. Source of material: Telford collection (fig. 36-40, 70-73).

Host species. - Plica umbra (type host) and Plica plica (Iguanidae).

GeOGRAPHIC RANGE. - Known only from the type locality, vicinity of Georgetown, Guyana.

Plasmodium minasense tegui subsp. nov.

Diagnosis. - A parasite of Tupinambis teguixin, the tegu. Schizonts 0.4 to 0.9 times the size (LW) of uninfected erythrocyte nuclei, 3-6 $\times 3-5 \mu \mathrm{m}$, with $4-6$ nuclei arranged in a broadly fan-shaped or cruciform schizont. Gametocytes 3-5 $\times 3-4 \mu \mathrm{m}$, with LW values $12-20 \mu \mathrm{m}^{2}$ and $\mathrm{L} / \mathrm{W}$ ratios $1.0-1.5$. Ratio of gametocyte $\mathrm{LW}$ to that of host cell nucleus 0.4-0.8. Pigment granules small and dark greenish-yellow to black in schizonts, greenish-black in gametocytes and present as one or two large grains often situated peripherally. Both schizonts and gametocytes are strongly nucleophilic in position within the host cell. Vacuole large and prominent in asexual stages, disappearing as schizonts mature. Short cytoplasmic projections commonly seen in younger asexual stages. Gametocytes usually show one to three very small vacuoles. Source of material: Telford collection (fig. 41-45, 74-77). 

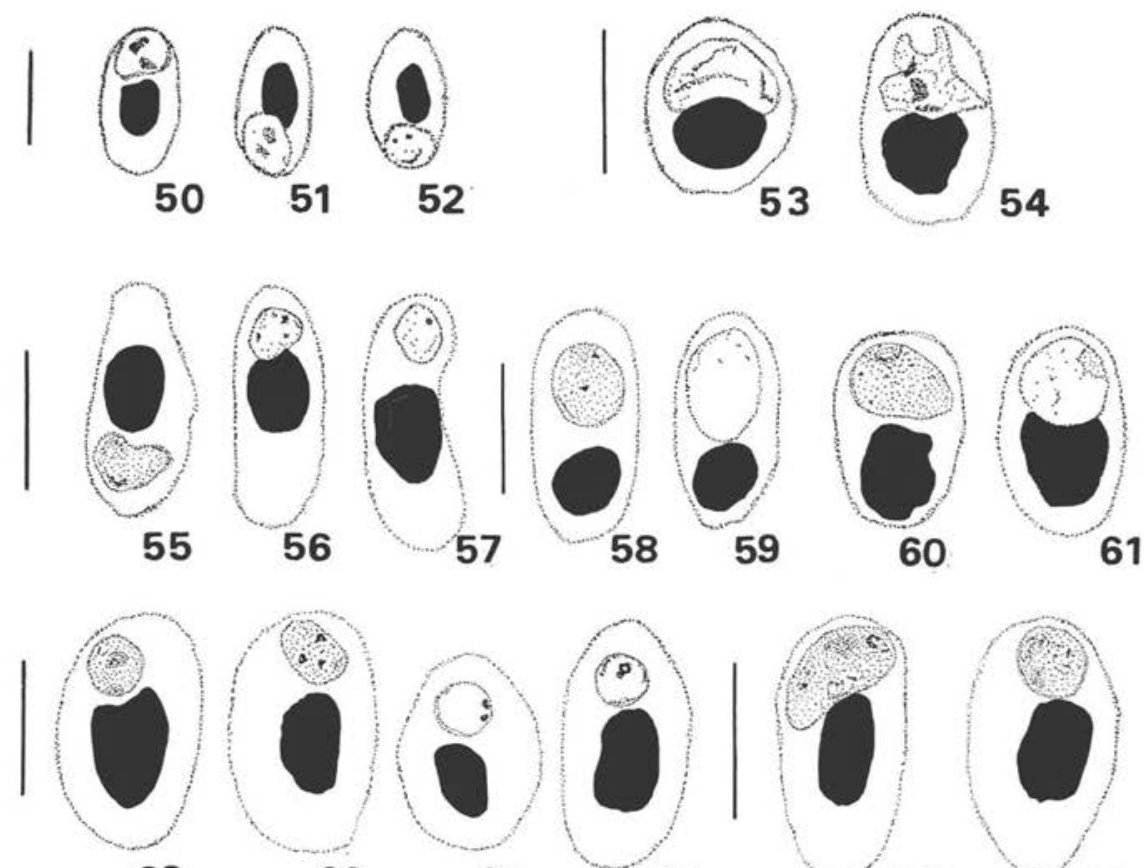

63
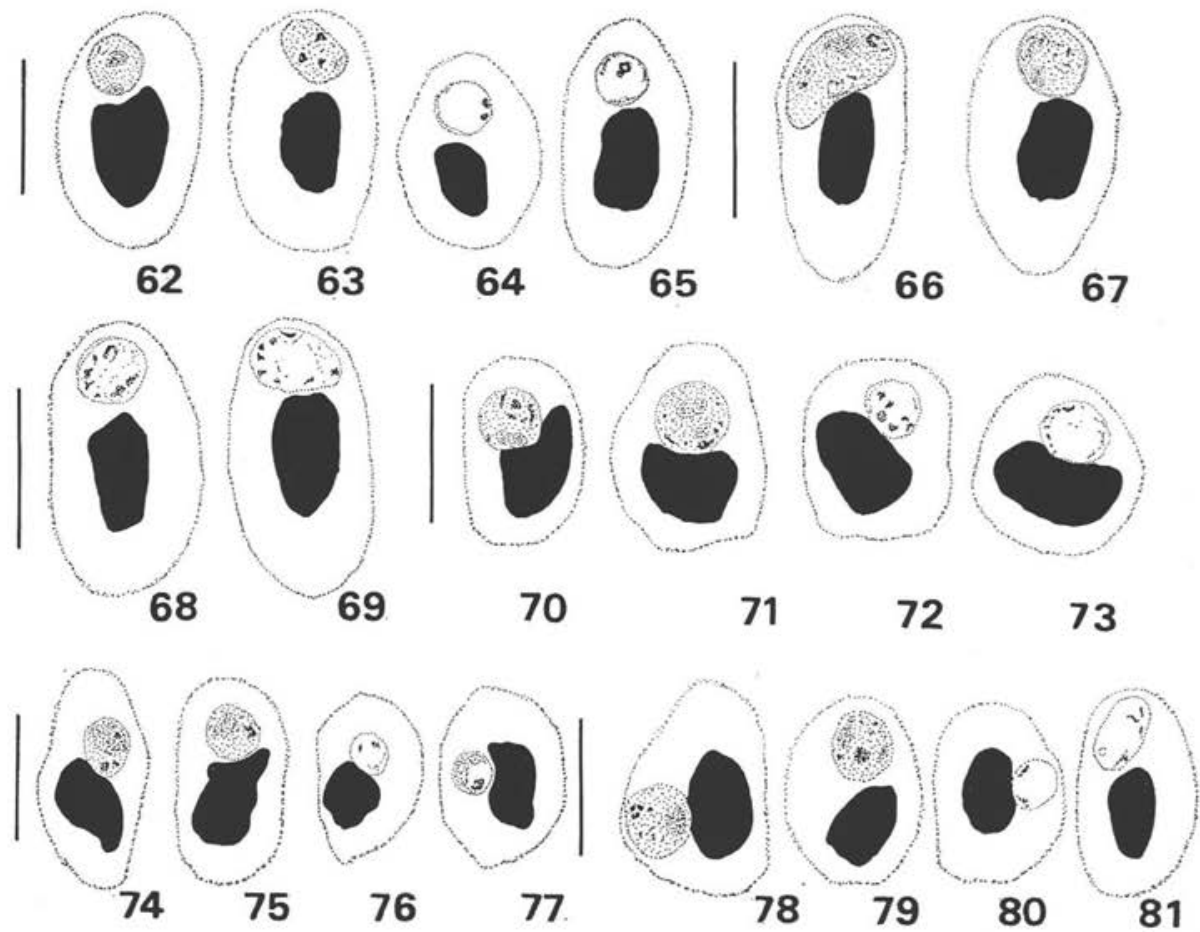
Host SPECIES. - Tupinambis teguixin (Teiidae), type host.

Geographic range. - Type locality is San Jorge, Municipio Piritú, Estado Portuguesa, Venezuela. Known with certainly only from the upper llanos of Venezuela. Malarial parasites reported from Tupinambis species of Colombia (Ayala et al., 1973), Guiana (Leger, 1919) and Brasil (Landau et al., 1974) probably refer to this species.

Plasmodium minasense diminutivum Telford, 1973.

\section{New Combination}

Diagnosis. - A parasite of Ameiva ameiva praesignis. Schizonts one-third to nearly equal size of uninfected erythrocyte nuclei, 3-4 $\times 3-4 \mu \mathrm{m}$, with 4-6 nuclei arranged in a slightly elongate, fan-shaped schizont. Gametocytes 5-7 $\times 4-6 \mu \mathrm{m}$, with LW values 20-42 $\mu \mathrm{m}^{2}$, and L/W ratios 1.0-1.5. Ratio of gametocyte LW to that of host cell nucleus 0.7-1.5. Pigment mass prominent, yellowish-gray in schizonts, often present as a single aggregation in gametocytes with several darker granules scattered throughout the cytoplasm. Vacuole large and prominent in asexual stages, disappearing as segmentation approaches, and seldom seen in gametocytes. Source of material: Telford collection (fig. 46-49, 78-81).

Host species. - Ameiva ameiva praesignis (Teiidae), type host.

Geographic RAnge. - Type locality is Guayabalito Village, Rio Chagres, Colon Province, Panama. Known only from central Panama in vicinity of the Canal Zone.

\section{Discussion}

The principal differences, apart from host and geography, which serve to separate subspecies of $P$. minasense are schizont size and shape, gametocyte shape, degree and character of pigmentation, and position of parasites relative to the host cell

Fig. 50-52. Gametocytes of $P$. minasense minasense from original description by Carini and Rudolph 1912

Fig. 53-54. Gematocytes supposedly of $P$. minasense carinii from Wenyon, 1915

Fig. 55-57. Gametocytes of $P$. minasense carinii supposedly from vicinity of Barranquilla, Colombia

Fig. 58-59. Gametocytes of $P$. rhadinurum from Colima, Mexico

Fig. 60-61. Gametocytes of $P$. rhadinurum from Estado Portuguesa, Venezuela

Fig. 62-65. Gametocytes of $P$. minasense anolisi from Panama

Fig. 66-69. Gametocytes of $P$. minasense capitoi from Panama

Fig. 70-73. Gametocytes of $P$. minasense plicae from Guyana

Fig. 74-77. Gametocytes of $P$. minasense tegui from Venezuela

Fig. 78-81. Gametocytes of $P$. minasense diminutivum from Panama

Vertical bars to left of figures represent $10 \mu \mathrm{m}$ 
nucleus. As far as can be determined from the single illustration in the type description, schizonts are comparatively larger in P. minasense minasense (fig. 1 ), and smallest in P. minasense plicae (fig. 36-40). A fan shape is characteristic of all populations. However, $P$. minasense anolisi commonly shows a rosette form $(20 \%)$, and also produces significantly more merozoites in proerythrocytes than in erythrocytes, a character not yet demonstrated for other subspecies. Cruciform schizonts are especially common in P. minasense tegui $(35 \%)$ and capitoi $(25 \%)$, somewhat less so in carinii $(12 \%)$ and anolisi $(4 \%)$. Schizonts of $P$. minasense diminutivum are invariably fan-shaped until segmentation is completed when they are occasionally seen in cruciform display of merozoites. This population has the most elongate and narrow schizonts of any of the subspecies. While all populations may show vacuoles commonly in young asexual stages, they are very large and most prominent in P. minasense diminutivum and tegui. In the latter population schizonts tend to be nucleophilic, while in $P$. minasense plicae they are often at the cell periphery. Both schizonts and gametocytes are far more variably shaped in $P$. minasense capitoi, and gametocytes especially are more heavily pigmented. Study of more material may indicate that this population should be recognized as a distinct species. Gametocytes of $P$. minasense carinii appear to be less regularly rounded or ovoid than in other populations, but too few have been seen to be certain. Pigment is less distinct in carinii, tegui, diminutivum and anolisi than in the others, and in the latter three tends to be localized in one or two spots within the gametocyte. Gametocytes of tegui and plicae are strongly nucleophilic (fig. 70-77), and usually lie in polar positions in all populations. Multiply infected host cells are commonly seen with $P$. minasense tegui, diminutivum, plicae and anolisi, with three to five parasites commonly present.

Acceptance of the viewpoint that Plasmodium rhadinurum and $P$. minasense carinii are conspecific (Ayala, 1977, 1978; Ayala and Spain, 1976) should await the presentation of evidence instead of opinion as its sole basis. In my experience, $P$. rhadinurum is a well characterized species as described from Iguana iguana in Mexico (Thompson and Huff, 1944), and its most distinctive feature, the filamentous cytoplasmic projections produced by young asexual stages, have been reported or observed throughout the range of its host from Mexico into Brasil (Carini, 1945; Walliker, 1966). Frequency of their appearance seems to be variable. Two infections I studied from Colima, Mexico had prominent projections present in 60 and 75 percent of 150 asexual parasites. Two localities in Panama, Achiote in Colon Province and Sanbu River, Darien provided samples which showed one parasite of 100 and none of 150 , respectively, to have the projections. Three Venezuelan infections studied showed filamentous projections in 6-26 percent of asexual parasites, with an overall frequency of 16.8 percent $(\mathrm{N}=125)$. Reasons for this variability may include geographic variation among populations or the influence of host or parasite physiology and perhaps could be correlated with stage of infection. It would provide an interesting subject for investigation.

Other differences exist, however, in the material I have which convince me that two small malarial parasites are found in Iguana iguana in some portions of its range. 
Schizonts of $P$. rhadinurum from Mexico (fig. 8-13) and Venezuela (fig. 14-20) are larger relative to the host cell nucleus, more variably shaped, and contain merozoites in which the nuclei are usually thick, bluntly rounded, and larger than those which I identify as $P$. minasense carinii (fig. 21-26). These more consistently assume a fanshape (fig. 21-23, 26), with small, usually narrow and more sharply pointed merozoites, and are usually less than half the size of host cell nuclei. The reduction in size cannot be attributed to their being crisis forms as the several infections studied came from young iguanas and had not yet reached the acute phase. Gametocytes of $P$. rhadinurum are at least the size and often half again as large as their host cell nuclei in both Mexican (fig. 58, 59) and Venezuelan (fig. 60, 61) samples. Too few $P$. minasense carinii gametocytes have been seen to be certain, but these appear to be smaller than host cell nuclei (fig. 55-57), and are possibly less rounded or ovoid than those of $P$. rhadinurum.

In view of the impossibility of establishing the nature of Wenyon's material from Trinidad, it is probably best to ignore the question and base the description of $P$. minasense carinii solely upon that of Leger and Mouzels (1917), which contains no reference to filamentous cytoplasmic projections in asexual stages. The collection of new material from I. iguana in the Guianas as well as surveys currently in progress by Dr. Ayala in Colombia will hopefully clarify the question of whether one or two species of Plasmodium which produce 4 merozoites in schizonts occur in iguanas of northern South America.

\section{Bibliographie}

Ayala S. C. (1977): Plasmodia of Reptiles. In: Parasitic Protozoa. Vol. III. Gregarines, Haemogregarines, Coccidia, Plasmodia and Haemoproteids. J. P. Kreier, Ed., Academic Press, Publ. New York, pp. 267-309.

Ayala S. C. (1978) : Checklist, host index and annotated bibliography of Plasmodium from reptiles. J. Protozool., 25, 87-100.

Ayala S. C., Spain J (1976).: A population of Plasmodium colombiense sp. n. in the iguanid lizard Anolis auratus. J. Parasitol., 62, 177-189.

Carini A. (1945): Considerações sobre o Plasmodium rhadinurum (Thompson et Huff, 1944) da Iguana. Arq. Biol. (São Paulo), 29, 147-149.

Carini A., Rudolph M. (1912): Sur quelques hématozoaires de lézards au Brésil. Bull. Soc. Pathol. Exot., 5, 592-595.

Garnham P.C. C. (1966): Malaria parasites and other haemosporidia. Blackwell Sci. Publ., Oxford, $1118 \mathrm{p}$.

Laird M. (1960) : Malayan protozoa. 3. Saurian malaria parasites. J. Protozool., 7, 245-250.

Landau I., Lainson R., Boulard Y., Shaw J.-J. (1974): Transmission au laboratoire et description de l'hémogrégarine Lainsonia legeri (Lankesterellidae) parasite de lézards brésiliens. Ann. Parasitol. Hum. Comp., 49, 253-263.

Léger M. (1919): Hémogrégarine et Plasmodium du Tupinambis nigropunctatus. Bull. Soc. Path. Exot., 12, 217-220.

Léger M., Mouzels P. (1917) : Plasmodium d'Iguana nudicollis. Bull. Soc. Pathol. Exot., 10, 95-98.

Telford S. R. Jr. (1973 a) : Malaria parasites of the «borriguerro » lizard, Ameiva ameiva (Sauria : Teiidae) in Panama. J. Protozool., 20, 203-207. 
Telford S. R., Jr. (1973 $b$ ) : Saurian malarial parasites from Guyana: their effect upon the validity of the family Garniidae and the genus Garnia, with descriptions of two new species. Int. J. Parasitol., 3, 829-842.

Telford S. R., Jr. (1974): The malarial parasites of Anolis species (Sauria: Iguanidae) in Panama. Int. J. Parasitol., 4, 91-102.

Telford S.R., Jr. (1977): The distribution, incidence and general ecology of saurian malaria in Middle America. Int. J. Parasitol., 7, 299-314.

Telford S. R., Jr. (1978): The saurian malarias of Venezuela: haemosporidian parasites of gekkonid lizards. Int. J. Parasitol., 8, 341-353.

Telford S. R., Jr. (1979) : A taxonomic reconsideration of some Plasmodium species from iguanid lizards. Ann. Parasitol. Hum. Comp. (in press).

Thompson P.E., Huff C. G. (1944) : Saurian malarial parasites of the United States and Mexico. J. Inf. Dis., 74, 68-79.

Walliker D. (1966) : Malaria parasites of some Brazilian lizards. Parasitol., 56, 39-44.

Wenyon C.M., 1915: The pigmented parasites of cold-blooded animals, with some notes on a plasmodium of the Trinidad iguana. J. Trop. Med. Hyg., 18, 133-140. 